\title{
CHEMICAL SYNTHESIS AND ANALYSIS OF ANTIMICROBIAL AND HEMOLYTIC ACTIVITY OF STRUCTURAL ANALOGOUS OF A PEPTIDE PROTEGRIN 1
}

\author{
P.M. Kopeykin ${ }^{1}$, M.S. Sukhareva ${ }^{1,2}$, N.V. Lugovkina ${ }^{1}$, O.V. Shamova \\ ${ }^{1}$ Institute of Experimental Medicine, Saint Petersburg, Russia; \\ ${ }^{2}$ Peter the Great SPbPU, Saint Petersburg, Russia
}

\section{ХИМИЧЕСКИЙ СИНТЕЗ И АНАЛИЗ АНТИМИКРОБНОЙ И ГЕМОЛИТИЧЕСКОЙ АКТИВНОСТИ СТРУКТУРНОГО АНАЛОГА ПЕПТИДНОГО ПРОТЕГРИНА 1}

\author{
П.М. Копейкин ${ }^{1}$, М.С. Сухарева ${ }^{1,2}$, Н.В. Луговкина ${ }^{1}$, О.В. Шамова \\ ${ }^{1}$ ФГБНУ «Институт экспериментальной медицины», Санкт-Петербург \\ ${ }^{2}$ ФГБНУ ВО «Санкт-Петербургский политехнический университет Петра Великого», Санкт-Петербург
}

\begin{abstract}
Search for new tools for combating infectious diseases and investigation of molecular mechanisms of their antimicrobial action in in vitro and in vivo models are the urgent tasks of experimental medicine and pathophysiology. A promising direction for the development of new effective antibiotic drugs is creation of analogues of natural protective molecules that provide a host defense against pathogenic bacteria, in particular analogues of antimicrobial peptides of the innate immune system. The aim of our work was design, chemical synthesis and characterization of antimicrobial and hemolytic activity of a peptide protegrin 1 (PG1) structural variants. Three analogues of PG1 were produced and studied, it was shown that two PG1 variants exhibit a high activity against antibiotic-resistant bacteria. A comparative analysis of the hemolytic activity of the peptides towards human erythrocytes was carried out. The ways of further work directed to creation of novel antimicrobials based on a natural peptide PG1 for combating drug-resistant bacteria are outlined.
\end{abstract}

Keywords: antimicrobial peptides; protegrins; antibacterial activity.

Поиск новых средств борьбы с инфекционными заболеваниями и изучение молекулярных механизмов их противомикробного действия на моделях in vitro и in vivo является актуальной задачей экспериментальной медицины и патофизиологии. Перспективным направлением для разработки новых эффективных антибиотических лекарственных средств является создание аналогов природных защитных молекул, обеспечивающих противостояние макроорганизма патогенным бактериям, а именно аналогов антимикробных пептидов системы врожденного иммунитета. Целью нашей работы явились разработка, химический синтез и характеристика антимикробной активности аналогов пептида протегрина 1 (ПГ1). Синтезированы и исследованы три аналога ПГ1, показано, что два пептида проявляют высокую активность в отношении антибиотикоустойчивых бактерий. Проведен сравнительный анализ гемолитической активности пептидов в отношении эритроцитов человека. Намечены пути дальнейшей работы, направленной на создание на основе ПГ1 новых антимикробных препаратов для борьбы с антибиотикоустойчивыми бактериями.

Ключевые слова: антимикробные пептиды; протегрины; антибактериальная активность.

Introduction. Invention of antibiotics allowed combating to dangerous infections for many years. But nowadays bacteria developed resistance to many antimicrobial compounds using in clinics. A search for new pharmaceuticals for fighting the drug-resistant bacteria is an important goal of medical research. Solving of this problem may be connected with investigation of the endogenous host defense factors such as antimicrobial peptides of the innate immune system. Antimicrobial peptides (AMPs) are cationic molecules with varied structures. High antimicrobial activity of AMPs points to their possible usage as new antimicrobial medications. But there are limitations of the AMPs practical application: many of them are not stable in biological solutions, while others exert some toxicity for host cells, including the hemolytic activity. To overcome these problems the synthetic analogues of natural AMPs are developing for creation new peptides with improved characteristics. The aim of the present work was design, chemical synthesis and examination of antimicrobial and hemolytic activity of structural variants of a peptide protegrin 1 (PG1). Protegrins are beta-hairpin AMPs with marked broad-spectrum antimicrobial activity and high stability in serum [1]. But these peptides exert some hemolytic activity towards human erythrocytes, and therefore may cause side effects in the case their use as an antibiotic drug. We have designed a peptide PG-B7 that includes a disulfide bonded region of PG1 and a fragment of $\mathrm{N}$-terminal region of a caprine bactenecin ChBac7.5. Another PG1 analog - a truncated peptide - PG1 (5-16). And the third analog with the modification in a region from 4 to 11 amino acid residues - PG (4-11 mod). 
Material and methods. The peptides were produced onthe automatic peptide synthesizer Biotage Initiator Alstra, by Fmoc-tBu strategy on Rink-Amide resin (ChemMatrix, Iris Biotech). Amino acids were crosslinked using diisopropylcarbodiimide/oxyma in dimethylformamide, at $70{ }^{\circ} \mathrm{C}$ for 10 minutes. Some cysteine residues were protected by trityl group, while others - by $\mathrm{S}$-acetamidomethyl groups. Removing the peptides from the resin was carried out using trifluoroacetic acid with addition of water, thioanisole, triisopropylsilane; all groups except of S-acetylaminomethyl were detached. At the next step the peptides were analyzed and purified by RP-HPLC. Afterwards they were dissolved in phosphate buffer $\mathrm{pH} 6$ and free cysteines were oxidized by adding a few drops of concentrated hydrogen peroxide. The obtained peptides with linked first S-S bridge were purified using RP-HPLC. Then the simultaneous removal of S-acetylaminomethyl group with linking the second $\mathrm{S}-\mathrm{S}$ bridge was carried by adding methanol to the final concentration of $50 \%$, with several drops of iodine in methanol. The reaction was performed for 15 to $30 \mathrm{~min}$, monitoring by RP-HPLC. The obtained peptides with two S-S bridges were purified by RP-HPLC and dried down by lyophilization.

Antimicrobial activity of the obtained peptides was tested against a set of drug-resistant clinical isolates of bacteria (Acinetobacter baumannii, Klebsella pneumonia, Pseudomonas aeruginosa, E. coli) by use a broth microdilution assay [2]. Hemolytic activity of the peptides towards erythrocytes of healthy donors was estimated as described [3].
Results and discussion. The applied procedure of peptide synthesis allowed obtaining PG1 analogues with $95-98 \%$ of purity as was proved by MALDI TOF MS, analytical HPLC and electrophoresis. Examination of the antimicrobial activity of the peptides revealed that the activity of PG-B7 was, in general, similar with that of the parent peptide PG1 and minimal inhibitory concentrations (MICs) were ranged from $0.125 \mu \mathrm{M}$ to $4 \mu \mathrm{M}$ against drug-resistant Gram-negative ( $P$. aeruginosa, K. pneumonia, A. baumannii, E. coli) and Gram-positive ( $S$. aureus) bacteria. For the truncated PG1 analogue MICs were somewhat higher (therefore, the activity was lower) and consisted of 0.5 to $8 \mu \mathrm{M}$. The activity of the third analogue was low (MICs $>64 \mu \mathrm{M})$. The hemolytic activity of PG-B7 was lower than that of PG1: at antimicrobial concentrations $1.6 \mu \mathrm{M}, 3.1 \mu \mathrm{M}, 6.25 \mu \mathrm{M}$, $12.5 \mu \mathrm{M}$ the percentage of lysed red blood cells for PG1 consisted of $17.40 \pm 7.54 \%, 28.88 \pm 5.03 \%$, $38.42 \pm 8.00 \% ; \quad 61.53 \pm 3.66 \%$, respectively; for PG-B7 - 3.83 $\pm 1.14 \%, \quad 14.01 \pm 4.57 \%$, $27.75 \pm 5.71 \%, 50.38 \pm 5.71 \%$; for the truncated PG $(5-16)-0.02 \pm 0.29 \% ; 0.06 \pm 0.29 \% ; 1.6 \pm 0.6 \%$; $5.3 \pm 0.6 \%$. At the concentration of $100 \mu \mathrm{M}$ PG1 as well as its analogues PG-B7 and PG (7-16) exerted a significant hemolytic effect $-77-100 \%$. The analogue PG- had a lack of the hemolytic activity at the range of concentrations $1-100 \mu \mathrm{M}$.

Conclusion. The obtained results point to the way of a design of PG1 structural analogues with the lowered hemolytic activity and potent antimicrobial action against drug-resistant bacteria.

\section{Referenses}

1. Kokryakov VN, Harwig SS, Panyutich EA, et al. Protegrins: Leukocyte antimicrobial peptides that combine features of corticostatic defensins and tachyplesins. FEBS Lett. 1993;327:231-236.

2. Haney EF, Mansour SC, Hancock REW. Antimicrobial Peptides: An Introduction. In: Antimicrobial Peptides. Methods in Molecular Biology, vol. 1548. Ed. by P. Hansen. New York, NY: Humana Press; 2017. P. 3-22.

3. Antibacterial Peptide Protocols. Ed. by W. Shafer. Totowa, NJ: Humana Press Inc.; 1997. 267 p. 